\title{
Kernos
}

Revue internationale et pluridisciplinaire de religion grecque antique

30 | 2017

Varia

\section{Revue des actes de colloques, ouvrages collectifs et anthologies}

\section{(2) OpenEdition}

Journals

\section{Édition électronique}

URL : http://journals.openedition.org/kernos/2554

DOI : $10.4000 /$ kernos. 2554

ISSN : 2034-7871

Éditeur

Centre international d'étude de la religion grecque antique

\section{Édition imprimée}

Date de publication : 1 octobre 2017

Pagination : 365-381

ISSN : 0776-3824

\section{Référence électronique}

"Revue des actes de colloques, ouvrages collectifs et anthologies », Kernos [En ligne], 30 | 2017, mis en ligne le 10 octobre 2017, consulté le 24 septembre 2020. URL : http://journals.openedition.org/ kernos/2554 ; DOI : https://doi.org/10.4000/kernos.2554

Ce document a été généré automatiquement le 24 septembre 2020.

Kernos 


\section{Revue des actes de colloques, ouvrages collectifs et anthologies}

1 BALANDIER Claire (éd.), Nea Paphos. Fondation et développement urbanistique d'une ville chypriote de l'antiquité à nos jours. Études archéologiques, historiques et patrimoniales. Actes $d u 1^{e r}$ colloque international sur Paphos. Avignon 30, 31 octobre et 1er novembre 2012, organisé par Claire Balandier \& Eustathios Raptou, Bordeaux, Ausonius, 2016.

J.-P. Cayla, Y a-t-il eu un temple d'Aphrodite Paphienne à Nea Paphos ?Une nouvelle hypothèse à propos du culte de la déesse de la mer à Paphos, p. 275-285; J. Karageorghis, Le roi Nikokles et ses déesses, p. 287-300; Y. Vernet, Le culte d'Apollon à Nea Paphos et ses environs de la fondation de la ville à la domination romaine, p. 301-313.

BIERL Anton, LARDINoIS André (éd.), The Newest Sappho: P. Sapph. Obbink and P.GC inv. 105, Frs. 1-4. Studies in Archaic and Classical Greek Song, vol. 2, Leiden/Boston, Brill, 2016 (Mnemosyne Supplements, 392).

D. Obbink, The Newest Sappho: Text, Apparatus Criticus, and Translation, p. 13-33 ; D. Obbink,Ten Poems of Sappho: Provenance, Authenticity, and Text of the New Sappho Papyri, p. 34-54 ; J. Lidov, Songs for Sailors and Lovers, p. 55-109 ; R. P. Martin, Sappho, Iambist: Abusing the Brother, p. 110-126; K.A. Raaflaub, The Newest Sappho and Archaic Greek-Near Eastern Interactions, p. 127-147 ; E. Bowie, How Did Sappho's Songs Get into the Male Sympotic Repertoire?, p. 148-164; A.Lardinois, Sappho's Brothers Song and the Fictionality of Early Greek Lyric Poetry, p. 167-187; D. Boedeker, Hera and the Return of Charaxos, p. 188-207; D. Obbink, Goodbye Family Gloom! The Coming of Charaxos in the Brothers Song, p. 208-224; A.-E. Peponi, Sappho and the Mythopoetics of the Domestic, p. 225-237 ; L. Kurke, Gendered Spheres and Mythic Models in Sappho's Brothers Poem, p. 238265 ; E. Stehle, Larichos in the Brothers Poem: Sappho Speaks Truth to the Wine-Pourer, p. 266-292 ; L. Morgan, The Reception of Sappho's Brothers Poem in Rome, p. 293-301 ; A. Bierl, 'All You Need is Love': Some Thoughts on the Structure, Texture, and Meaning of the Brothers Song as well as on Its Relation to the Kypris Song (P. Sapph. Obbink), p. 302-336 ; A. Bierl, Sappho as Aphrodite's Singer, Poet, and Hero(ine): The Reconstruction of the Context and Sense of the Kypris Song, p. 339-352 ; S. Boehringer, C. Calame, Sappho and Kypris: 'The Vertigo of Love' (P. Sapph. Obbink 21-29 ; P. Oxy. 1231, fr. 16), p. 353-367 ; R. Schlesier, Loving, but not Loved: The New Kypris Song in the Context of Sappho's Poetry, p. 368-395 ; D. Rayor, 
Reimagining the Fragments of Sappho through Translation, p. 396-412 ; J. Lidov, Notes on the First Stanza of Fragment 17, p. 415-423 ; St. Caciagli, Sappho Fragment 17: Wishing Charaxos a Safe Trip?, p. 424-448 ; G. Nagy, A Poetics of Sisterly Affect in the Brothers Song and in Other Songs of Sappho, p. 449-492. Sanktionierung in der griechisch-römischen Antike. Akten einer deutsch-italienischen Tagung. Palermo, 11.-13. Dezember 2014, Stuttgart, Steiner, 2016.

D. Bonanno, P. Funke, M. Haake, Procedimenti giuridici e sanzione religiosa nel mondo greco $e$ romano: un excursus introduttivo, p.11-16;P. Funke, Was die Amphiktyonie im Innersten zusammenhält. Überlegungen zum Wechselspiel von Religion und Politik in zwischenstaatlichen Verfahren im frühen Griechenland, p. 19-33; N. Cusumano,Sanzione religiosa, procedimenti

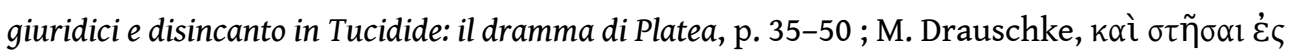

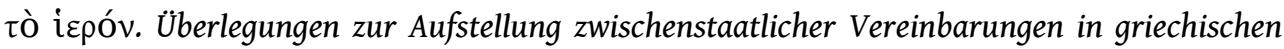
Heiligtümern, p.51-61; K. Knäpper, Eunoia, Eusebie, Euergesie. Positive Selbstcharakterisierung als Argumentationsstrategie in Asyliedokumenten des 3. und 2. Jh.s v. Chr., p. 63-74 ; D. Bonanno, Figlia della Notte e compagna di Aidos: Nemesis, dike e il senso del limite in Esiodo, p.103-114;G. Ingarao, Se a grandi ingiustizie corrispondono grandi punizioni. Alcune riflessioni sul lessico della sanzione divina in Erodoto, p. 115-125 ; S. Scharff, Wie versichert man sich der göttlichen Vergeltung? Ein rechtliches Verfahren und seine religiöse Sanktionierung in der Amnestie der Dikaiopoliten, p. 127-137 ;A.-S. Aletsee, Der Triumph des Transgressors. Plutarch, Alexander der Große und die Pythia (Plu. Alex. 14,6-7), p. 139-149 ; A. Lepke, Apollon kauft einen Sklaven. Legale Fiktion und göttliche Intervention in den delphischen Freilassungsinschriften, p. 151-161 ;E.-M. Kuhn, When justice will not fail. Zum kirchlichen Rechtsgang in der Spätantike, p. 191-203 ; M. Haake, Asebie als Argument. Zur religiösen Fundierung politischer Prozesse im klassischen und frühhellenistischen Griechenland: das Beispiel der athenischen Philosophenprozesse, p. 207-222 ; K. Zimmermann, Leges sacrae -antike Vorstellungen und moderne Konzepte. Versuch einer methodischen Annäherung an eine umstrittene Textkategorie, p. 223-232; C. Biagetti,Diritto e religione a Cuma eolica. Prime riflessioni, p. 233-243; A. Saggioro, Continuità e discontinuità nel trattamento giuridico della magia, p. 257-268 ;A. Filippini, Legislazione imperiale e processi giudiziari per crimini religiosi nell'Oriente romano tardoantico (IV-VI sec.) : le fonti epigrafiche, p. 307-316.

BONNECHERE Pierre, CURSARU Gabriela (éd.), Katábasis dans la tradition littéraire et religieuse de la Grèce ancienne. Actes du Colloque de Montréal et de Québec (2-5 mai 2014), vol. 1, Namur, 2015 (LEC, 83).

Pierre Bonnechere, Gabriela Cursaru, La catabase dans le monde grec entre son passé et son avenir, p. 3-13 ; Alberto Bernabé, What is a Katábasis? The Descent to the Netherworld in Greece and the Ancient Near East, p. 15-34 ; Jan N. Bremmer, Theseus' and Peirithoos' Descent into the Underworld, p. 35-49 ; Stamatia Dova, Theseus, Peirithoos, and the Poetics of a Failed Katábasis, p. 51-68 ; George Gazis, The Nekyia's Catalogue of Heroines: Narrative Unbound, p. 69-99 ; Marie-Claire Beaulieu, Ulysse et l'Hadès brumeux: catabase et anabase dans l' Odyssée, p. 101-115 ; Marco Antonio Santamaría Álvarez, The Parody of the KatábasisMotif in Aristophanes' Frogs, p. 117-136; Sara Macías Otero, On the Threshold of Hades: Necromancy and Nékyia in some Passages of Greek Tragedy, p. 137-153 ; Yann Leclerc, Les chemins de la catabase. Paysages des dieux, paysages des hommes, p.155-174; Daniela Bonanno, Jouer avec les dieux : la katábasis de Rhampsinite dans l'Hadès (Hdt., II, 122), p. 175192 ;Daniel Ogden, Katábasis and the Serpent, p. 193-210 ;Monique Halm-Tisserant, Les dessous de la katábasis : effets spéciaux et machineries?, p. 211-235 ;Ana Isabel Jiménez San 
Cristóbal, The Rape of Persephone in a Berlin Papyrus, p. 237-260 ;Radcliffe G. Edmonds, “ When I Walked the Dark Road of Hades": Orphic Katábasis and the Katábasis of Orpheus, p. 261-279 ;Renée Koch Piettre, Remonter d'une catabase burlesque à une övooos cosmique.

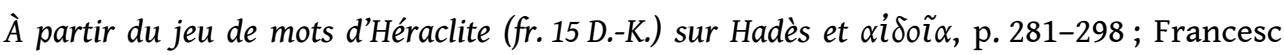
Casadesús Bordoy, The Myth of Er: Between Homer and Orpheus, p. 299-311; Renaud Gagné, La catabase aérienne de Thespésios: le statut du récit, p. 313-328; Miguel Herrero De Jáuregui, Traditions of Catabatic Experience in Aeneid 6, p.329-349; Hedvig Von Ehrenheim, Death and Ascent of Hyakinthos in Sparta: Ritual Mourning and Feasting, p. 351364 ; Matthew R. Anderson, Jean-Michel Roessli, La catabase d'Orphée dans la poésie portugaise de la Renaissance, p. 427-444.

BONNET Corinne, PIRENNE-DELFORGE Vinciane, PIRONTI Gabriella (éd.), Dieux des Grecs, dieux des Romains. Panthéons en dialogue à travers l'histoire et l'historiographie, Bruxelles/Roma, Belgisch Historisch Instituut te Rome, 2016.

C. Bonnet, V. Pirenne-Delforge, G. Pironti, Dieux des Grecs, dieux des Romains : en guise d'ouverture, p. 7-16 ; M. Bettini, Interpretatio Romana: Category or Conjecture?, p. 17-35; J. Scheid, Moerae, Ilithyiae, Terra mater, des Grecques très romaines, p. 37-43; N. Belayche, La Mater Magna, Megalè Mètèr?, p. 45-59; S. Paul, Nommer les dieux romains en Grèce. Épicleses grecques et latines en interaction dans la pratique dédicatoire, p.61-77; E. Stavrianopoulou, From the god who listened to the god who replied: Transformations in the concept of epekoos, p. 79-97 ; S. Caneva, Configurations publiques de Dionysos dans le cadre de l'hellénisation de Rome, p. 99-116; F. Massa, Liber face à Dionysos: une assimilation sans écarts ?Koine dionysiaque et pratiques rituelles romaines, p.117-129; V. Huet, Mars et ses images sur les reliefs romains: un corps d'Arès pour des rites romains?, p. 131-155; C. Jourdain-Annequin, Dieux de la Grèce et dieux de Rome en son empire. L'exemple d'Héracles/Hercule dans les Alpes occidentales, p. 157-171; C. Pisano, Divine Configurations of 'Pity' in Greece and Rome: Eleos and Clementia, p.173-186; A. Saggioro, Vacuna un cas d'ecole, p. 187-198; F. Van Haeperen, Les dieux publics outragés par Verrès, p. 199-210 ; E. Rosso, Isotheoi timai. Les empereurs, les 'honneurs divins' et leur refus, entre Orient et Occident, p. 211-228; Ph. Borgeaud, Jérôme traducteur et la Mère des dieux (Commentaire à Osée), p. 229-238.

BOSCHUNG Dietrich, HÖLKESKAMP Karl-Joachim, sODE Claudia (éd.), Raum und Performanz. Rituale in Residenzen von der Antike bis 1815, Stuttgart, Steiner, 2015.

K.-J. Hölkeskamp, 'Performative turn' meets 'spatial turn'. Prozessionen und andere Rituale in der neueren Forschung, p.15-74; P. F. Mittag, Der potente König. Königliche Umzüge in hellenistischen Hauptstädten, p. 75-97; E. Flaig, Prozessionen aus der Tiefe der Zeit. Das Leichenbegängnis des römischen Adels - Rückblick, p. 99-126; E. Stein-Hölkeskamp, Zwischen Parodie und Perversion. Verkehrungen des Triumphes in der frühen Kaiserzeit, p. 127-142 ; D. Boschung, Architektur und Ritual. Zum Auftreten der Kaisers in Rom, p. 143166.

7 Bouton-Touboulic Anne-Isabelle,LÉVyCarlos(éd.), Scepticisme et religion. Constantes et évolutions, de la philosophie hellénistique à la philosophie médiévale, Turnhout, Brepols, 2016 (Monothéismes et Philosophie).

Anna Maria Ioppolo, La critique de Carnéade sur la divination, p. 41-56; Carlos Lévy, De l' epochèsceptique à l'epochè transcendantale: Philon d'Alexandrie fondateur du fidéisme, p. 57-73 ; Mauro Bonazzi, Le platonisme de Plutarque de Chéronée entre scepticisme, théologie et métaphysique, p. 75-88; Emidio Spinelli, «Le dieu est la cause la plus active »: Sextus Empiricus contre la théologie dogmatique, p. 89-102; Stéphane Marchand, Religion et piété 
sceptique selon Sextus Empiricus, p. 103-117 ; Brigitte Pérez-Jean, Ne pas dire le principe: usage sceptique et usage théologique de la négation, p.119-135; Gábor Kendeffy, L'appropriation des arguments néoacadémiciens par Lactance, p. 137-155.

BURGERSDIJK Diederik, CALIS Richard, KELDER Jorrit, SOFRONIEW Alexandra, TUSA Sebastiano, VAN BEeK René (éd.), Sicily and the Sea, Zwolle/Amsterdam, WBOOKS/Allard Pierson Museum, 2015.

K. Neeft, Demeter on Sicily, p. 52-55 ;P. Beliën, Between Rivers and Seas: Aquatic Images on Greek Coins from Sicily, p. 56-61; F. van den Eijnde, Temples and Community in Greek Sicily, p. 68-71;P. Gerbrandy, Sicily in the Rape of Proserpine by Claudian, p. 104-111.

CALAME Claude, ellinger Pierre (éd.), Du récit au rituel par la forme esthétique. Poèmes, images et pragmatique cultuelle en Grèce ancienne, Paris, Les Belles Lettres, 2017.

Claude Calame, La forme poétique pour transformer le récit héroïque en pratique rituelle: la pragmatique du Péan 6 de Pindare, p. 17-45; Ewen Bowie, Un contexte rituel pour le Télèphe d'Archiloque?, p. 47-71; Lucia Athanassaki, Poésie mélique, récit et rituel: une relation simple ?Sur les Olympiques 4 et 5 de Pindare, p. 73-96; David Bouvier, Comment chanter Néoptolème? La Néméenne 7 de Pindare entre rituel et poésie ou les limites d'une analyse intertextuelle, p. 97-129 ; Pierre Ellinger, La seconde chance: Artémis et Héra dans la $11^{e}$ É pinicie de Bacchylide, p.131-160; Louise Bruit Zaidman, L'Iphigénie en Tauride d'Euripide: Artémis entre deux sacrifices humains, p. 161-183; Carlo Brillante, Du côté des Muses: les gardiennes de la parole poétique entre mythe et culte, p. 185-218; François Lissarague, Image, signe, récit : le cas des armes de Thésée, p. 219-240 ; Vinciane PirenneDelforge, Gabriella Pironti, Humnétriai, choeur de jeunes filles... un rite mis en image chez Philostrate, p. 241-268; Jan Bremmer, Mythe et rituel dans l'initiation d'Héraclès, p. 269304 ; Roger Woodard, Bellérophon et l'agressivité féminine: diachronie et synchronie dans les mythes et la pratique rituelle, p. 305-332.

CAREY Christopher, EDWARDS Michael (éd.), Marathon-2,500 Years. Proceedings of the Marathon Conference 2010, London, Institute of Classical Studies, University of London, 2013 (BICS, suppl. 124).

A. Gartiou-Tatti, Gods, heroes and the battle of Marathon, p.91-110; A. Mastrapas, The battle of Marathon and the introduction of Pan's worship to Athens: the political dimension of a legend through written evidence and archaeological finds, p. 111-122; E. Papadodima, The Battle of Marathon in fifth-century drama, p. 143-154 ; I. Karamanou, As threatening as the Persians: Euripides in Aristophanes' Thesmophoriazusae, p. 155-164 ; E. Volonaki, The Battle of Marathon in funeral speeches, p. 165-179.

11 CARPENTER Thomas H., LANGRIDGE-NOTI Elizabeth, STANSBURY o'Donnell Mark D. (éd.), The Consumer's Choice. Uses of Greek Figure-Decorated Pottery, Boston, Archaeological Institute of America, 2016 (Selected Papers on Ancient Art and Architecture, 2).

A. Jiang, Karneia and Kitharoidos: Rereading a Laconian Cup in the Michael C. Carlos Museum, p. 23-40 ; B. Peruzzi, Eggs in a Dringing Cup: Unexpected Uses of a Greek Shape in Central Apulian Funerary Contexts, p. 65-81; V. Saripanidi, Too Young to Fight (or Drink): A Warrior Krater in a Child Burial at Ancient Sindos, p. 83-103.

12 CAVALIERI Marco, LEBRUn René, MEUNIER Nicolas L. J. (éd.), De la crise naquirent les cultes. Approches croisées de la religion, de la philosophie et des représentations antiques. Actes du Colloque international organisé à Louvain-la-Neuve les 12 et 13 juin 2014 par le Centre d' étude des Mondes Antiques, le Centre d'Histoire des religions Cardinal Julien Ries et les Actions 
de Recherche Concertées «A World in Crisis?», Turnhout, Brepols, 2015 (Homo Religiosus Série II, 15).

Giusto Traina, "Guerre sainte »et appropriation des dieux ennemis : quelques considérations, p. 19-28; Jan Driessen, The Birth of a God? Cults and Crises on Minoan Crete, p. 31-44; Charles Doyen, La tablette PY Tn 316: un Crisis Cult ?, p. 65-83 ; Patrick Marchetti, Le « crétois "Épiménidès et la crise de la société grecque à l'époque archaïque, p. 85-98; Rachele Dubbini, La réorganisation des cultes dans l'agora de Corinthe après la crise du vie siècle av. J.-C., p. 99-112; Christophe Flament, Crise des cultes et cultes de crise à Athènes durant la guerre du Péloponnèse?, p. 113-130; Aikaterini Lefka, Platon : réactions d'un philosophe face à la crise de la religion traditionnelle, p. 131-144; Nicolas L. J. Meunier, Le lac Régille, les Dioscures et Cérès: de la crise romano-latine à la crise patricio-plébéienne, p.147-166; Bernard Mineo, D'une crise religieuse à une autre: de l'Apollon de Fabius Pictor à celui d'Auguste, p. 167-188; Pierre Assenmaker, Un panthéon de crise : dévotions et cultes durant l'année des quatre empereurs (68-69 ap. J.-C.), p. 189-204 ; Nicolas Amoroso, Objets isiaques en contexte domestique durant l'Antiquité tardive à Athènes et à Rome: le cas des images associant Isis à Tyché/Fortuna, p. 207-232; Vincent Mahieu, Acteurs, lieux et pratiques du culte de Vesta dans la Rome tardo-antique. Vitalité et disparition d'une institution de la religion traditionnelle, p. 233-249; Carla Sfameni, Crisi e «privatizzazione »dei culti in età tardoantica: il contributo dell'archeologia delle ville, p.251-271; Marco Cavalieri, A fundamentis ipsam basilicam exterminauit. Espaces et cultes à Rome du $\mathrm{IV}^{e}$ au vi siècle de notre ère, p. 273-306.

13 CAzZATo Vanessa, obBing Dirk, PRODi Enrico Emanuele (éd.), The Cup of Song. Studies on Poetry and the Symposion, Oxford, Oxford University Press, 2016.

V. Cazzato, E. E. Prodi, Introduction: Continuity in the Sympotic Tradition, p.1-16; O. Murray, The Symposion between East and West, p.17-27;E. Bowie, Quo usque tandem...? How Long Were Sympotic Songs?, p. 28-41; G. Liberman, Some Thoughts on the Symposiastic Catena, Aisakos, and Skolia, p.42-62; G. B. D'Alessio, Bacchylides' Banquet Songs, p. 63-84;L. Athanassaki, The Symposion as Theme and Performance Context in Pindar's Epinicians, p. 85-112;G. Hedreen,Smikros, Fictional Portrait of an Artist as a Symposiast by Euphronos, p. 113-139; R.M. Rosen, Symposia and the Formation of Poetic Genre in Aristophanes' Wasps, p. 140-158 ;D.T. Steiner, Parting Shots: Aeschylus, Agamemnon 1384-98 and Symposia in the Visual Repertoire, p. 159-183 ; V. Cazzato, Symposia en plein air in Alcaeus and Others, p. 184-206 ; R. Gagné,The World in a Cup: Ekpomatics in and out of the Symposion, p.207-229; A. Sens, Party or Perish: Death, Wine, and Closure in Hellenistic Sympotic Epigram, p. 230-246; G.O. Hutchinson, Hierarchy and Symposiastic Poetry, Greek and Latin, p. 247-270.

14 Clauss James J., CUYPERS Martine, KAHANE Ahuvia (éd.), The Gods of Greek Hexameter Poetry. From the Archaic Age to Late Antiquity and Beyond, Stuttgart, Steiner, 2016 (Potsdamer Altertumswissenschaftliche Beiträge, 56).

J.J. Clauss, Martine Cuypers, A. Kahane, Hiero's Question: An Introduction, p.1-17 ; J. Strauss Clay, The Justice of Zeus in the Theogony?, p. 21-31; A. Faulkner, The Gods in the Narratives of the Homeric Hymns, p. 32-42; K. Ormand,Divine Perspective and the Plots of Zeus in the Hesiodic Catalogue, p. 43-59 ; J. Marks, Herdings Cats: Zeus, the Other Gods, and the Plot of the Iliad, p. 60-75 ; R.P. Martin, Poseidon in the Odyssey, p. 76-94 ; Ch. Tsagalis, The Gods in Cyclic Epic, p. 95-117 ;T. Heckenlively, Ares in the Pseudo-Hesiodic Shield, p. 118-132 ; J.J. Clauss, Heldendämmerung Anticipated: The Gods in Apollonius'Argonautica, p. 135-151 ; J. Ryan, Zeus in Aratus' Phaenomena, p. 152-163 ; I. Petrovic,Gods in Callimachus' Hymns, 
p. 164-179; M. Giuseppetti, Gods in Fragments: Callimachus' Hecale, p. 180-196 ; A.D. Morrison, Erotic Battles? Love, Power-Politics and Cosmic Significance in Moschus' Europa and Eros on the Run, p. 197-211 ; S. Bär, Reading Homer, Writing Troy: Intertextuality and Narrativity of the Gods and the Divine in Quintus of Smyrna's Posthomerica, p. 215-230 ; L. Miguélez-Cavero, 'With a Little Help from my (Divine) Friends': Double Motivation and Personification in Triphiodorus' Sack of Troy, p. 231-242; A. Bartley, The Huntress and the Poet: Artemis in the Cynegetica, p. 243-255 ; D. Accorinti, Naming the God of Metamorphosis: The Ever-changing Shape of the Infant Dionysus in Nonnus' Dionysiaca, p. 256-267 ; E. Magnelli,Gods and Men in Colluthus' Rape of Helen, 288-297;O. Schelske, The Argonautica of Orpheus as 'Poetic Theology'? Divine Hierarchies in Late Antique Philosophy and Poetry, p. 298-308 ; J.L. Lightfoot,Polytheism in the Sibylline Oracles, p. 309-335 ; W. Briggs, Homer's Gods and Virgil's Aeneid, p. 339-352 ; F. Graf, The Gods in Ovid's Fasti, p. 353-366 ; E. Adams, From Epiphanic Idyll to Faith-bound Epyllia: Tennyson's Poetic Descent from Virgil to Gibbon, p. 367-384 ; A. Kahane, Modernity and the Twilight of the Epic Gods: Reading Derek Walcott and Alice Oswald, p. 385-406.

COLESANTI Giulio, Lulli Laura (éd.), Submerged Literature in Ancient Greek Culture. Case Studies, Berlin/Boston, de Gruyter, 2016.

E. Lippolis, Sacred Texts and Consecrated Texts, p. 125-160 ;S. Ribichini, Covered by Silence: Hidden Texts and Secret Rites in the Ancient Mystery Cults, p. 161-176 ;F. Ferrari, Orphics at Olbia?, p. 177-186 ;M. D’Acunto, Dance in Attic and Argive Geometric Pottery: Figurative Imagery and Ritual Contexts, p. 205-241 ;L. Cerchiai, Ariadne and Her Companions, p. 259267.

CORTÉS COPETE Juan Manuel, MUÑIZ GRIJALVo Elena, LOZANO GóMEZ F. (éd.), Ruling the Greek World. Approaches to the Roman Empire in the East, Stuttgart, Steiner, 2015 (Potsdamer Altertumswissenschaftliche Beiträge, 52).

E. Muñiz Grijalvo, Greek Religion as a Feature of Greek Identity, p. 27-42;A. Lozano, Imperium Romanum and the Religious Centres of Asia Minor. The Invention of Roman Political Power on the Temples of Asia Minor, p. 67-90 ;F. Lozano, R. Gordillo, A Dialogue on Power: Emperor Worship in the Delphic Amphictyony, p. 127-145.

CUEVA Edmund P., Martínez Javier (éd.), Splendide Mendax. Rethinking Fakes and Forgeries in Classical, Late Antique, and Early Christian Literature, Groningen, Barkhuis, 2016.

V. Prosperi, The Trojan War: Between History and Myth, p.93-111; E. Ruiz Yamuza, Protagoras's Myth: Between Pastiche and Falsification, p.113-124; J. Filonik, Impiety Avenged: Rewriting Athenian History, p. 125-140 ; K. Lennartz, Not without My Mother: The Obligate Rhetoric of Daphne's Transformation, p. 193-203

DAKOURI-HILD Anastasia, BOYD Michael J. (éd.), Staging Death. Funerary Performance, Architecture and Landscape in the Aegean, Berlin/Boston, de Gruyter, 2016.

M.J. Boyd, A. Dakouri-Hild, Staging Death: an Introduction, p. 1-9 ; A. Dakouri-Hild,Getting to Funerary Place in a Fairly Short Stretch of Time: Death and Performance in the Prehistoric Aegean, p. 11-30; M. Chountasi,Funerary Ritual-Architectural Events in the Temple Tomb and the Royal Tomb at Knossos, p. 33-55; M.J. Boyd,Fields of Action in Mycenaean Funerary Practices, p. 57-87 ; A. Van de Moortel, Politics of Death at Mitrou: Two Prepalatial Elite Tombs in a Landscape of Power, p. 89-113 ; K. Sarri, Intra, Extra, Inferus and Supra Mural Burials of the Middle Helladic Period: Spatial Diversity in Practice, p. 117-138; K. Harrell, The Practice of Funerary Destruction in the Southwest Peloponnese, p. 139-154; Y. Galanakis, A Roof for the Dead: Tomb Design and the 'Domestication of Death' in Mycenaean Funerary 
Architecture, p. 155-177 ; A. Lagia, I. Moutafi, R. Orgeolet, D. Skorda, J. Zurbach, Revisiting the Tomb: Mortuary Practices in Habitation Areas in the Transition to the Late Bronze Age at Kirrha, Phocis, p. 181-205 ;B. Cavanagh, A. Lagia, Ch. Mee (†), Mortuary Practices in the Middle Bronze Age at Kouphovouno: Vernacular Dimensions of the Mortuary Ritual, p. 207-225 ; I. Schoep, P. Tomkins, 'Death Is Not the End': Tracing the Manipulation of Bodies and Other Materials in the Early and Middle Minoan Cemetery at Sissi, p. 227-250 ; G. Vavouranakis, A Posthumanocentric Approach to Funerary Ritual and its Sociohistorical Significance: the Early and Middle Bronze Age Tholos Tombs at Apesokari, Crete, p. 253-273 ; E. Miller Bonney, From Performing Death to Venerating the Ancestors at Lebena Yerokambos, Crete, p. 275-295 ; A. Labrude, Aegean Late Bronze and Early Iron Age Burials in the Ruins of Rulers' Dwellings: a Legitimisation of Power?, p. 297-314; O. Dickinson, Continuities and Discontinuities in Helladic Burial Customs During the Bronze Age, p. 317-333 ; N. Papadimitriou,Structuring Space, Performing Rituals, Creating Memories: Towards a Cognitive Map of Early Mycenaean Funerary Behaviour, p. 335-360 ; S. Farnham,Pollution and Purity in the Argolid and Corinthia During the Early Iron Age: the Burials, p. 361-388.

DERRON Pascale (éd.), Cosmologies et cosmogonies dans la littérature antique, Genève, Fondation Hardt, 2015 (Entretiens sur l'antiquité classique, 61).

J. Strauss Clay, Commencing cosmogony and the rhetoric of poetic authority, p. 105-147; R. Brague, Dans quelle mesure peut-on parler d'une cosmologie dans l'Antiquité?, p. 291-315. DES COURTILS Jacques (éd.), L'architecture monumentale grecque au III' siècle a.C., Bordeaux, Ausonius, 2015 (Mémoires, 40).

D. Laroche, L'architecture à Delphes au III' s. a.C., p. 21-28;E. Partida, Architectural elements and historic circumstances that shaped the Sanctuary of Delphi during the so-called 'Age of the Warriors', p. 29-50;Y. Lolos, L'architecture à Sicyone pendant la haute époque hellénistique, p. 51-82 ;G. Stanzl, Das Ptolemaion von Limyra, p. 175-196.

21 DI DONATo Riccardo (éd.), Comincio a cantare. Contributi allo studio degli Inni Omerici, Pisa, Edizioni ETS, 2016 (Anthropoi. Studi e materiali di Antropologia storica del mondo antico, 13).

E. Colangelo, Unità e struttura dell' Inno Omerico ad Apollo (III), p. 1-13 ; S. Fanucchi, L' Inno Omerico a Hermes (IV) et il dramma satiresco Ichneutae di Sofocle, p.15-30;

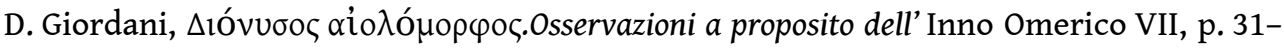

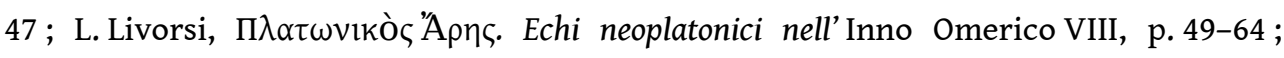
L. Niccolai, L' Inno Omerico a Pan (XIX) et la fondazione della Lega Arcadica: une proposta di contestualizzazione, p. 65-82 ; M.A. Rodda, L'Inno Omerico ad Afrodite (V) e la cronologia relativa dell'epica greca arcaica, p. 83-101. DIGNAS Beate, PARKer Robert, stroumSA Guy G. (éd.), Priests and Prophets among Pagans, Jews and Christians, Leuven/Paris/Walpole, Peeters, 2013 (Studies in the History and Anthropology of Religion, 5).

J. Scheid, Priests and Prophets in Rome, p. 15-28 ; N. McLynn, Aelius Aristides and the Priests, p. 52-79 ; B. Dignas, Greek Priests in the First Three Centures CE: Traditional, Diverse, Wholly New?, p. 80-111; N. Belayche, Priests as Diviners: An Impact on Religious Changes in Imperial Anatolia?, p. 112-135; J.N. Bremmer, The Representation of Priests and Priestesses in the Pagan and Christian Greek Novel, p. 136-161.

ERCOLANI Andrea, GIORDANO Manuela (éd.), Submerged Literature in Ancient Greek Culture. Volume 3: The Comparative Perspective, Berlin/Boston, de Gruyter, 2016. 
J. Ben-Dov, The Resurrection of the Divine Assembly and the Divine Title El in the Dead Sea Scrolls, p. 9-31;L. Pucci, The Purification of Orestes at Troezen, p. 71-94 ; G.G. Stroumsa, Modes of Scriptural and Personal Authority in Late Antique Religion, p. 169-182.

efstathiou Athanasios, KARAMAnou Ioanna(éd.), Homeric Receptions Across Generic and Cultural Contexts, Berlin/Boston, de Gruyter, 2016 (Trends in Classics, 37)

I. Karamanou, Introduction: The Contexts of Homeric Reception, p.1-11; L. Hardwick, Homer, Repetition and Reception, p.15-27; M. Alexandrou, Hipponax and the Odyssey: Subverting Text and Intertext, p. 31-44 ; A. Petrovic, Archaic Funerary Epigram and Hector's Imagined Epitymbia, p. 45-58 ; M. Sotiriou, Performance, Poetic Identity and Intertextuality in Pindar's Olympian 4, p. 59-69 ; Ch. Carey, Homer and Epic in Herodotus' Book 7, p. 71-89; A. Efstathiou, Argumenta Homerica: Homer's Reception by Aeschines, p. 93-123 ; E. Volonaki, Homeric Values in the Epithaphios Logos, p. 125-145 ; I.N. Perysinakis, The Ancient Quarrel between Philosophy and Poetry: Plato's Hippias Minor, p. 147-161; K. Mantzouranis, A Philosophical Reception of Homer: Homeric Courage in Aristotle's Discussion of $\dot{\alpha} v \delta \rho \varepsilon i ́ \alpha$, p. 163-173 ; Ch.-P. Manolea, Homeric Echoes, Pythagorean Flavour: The Reception of Homer in

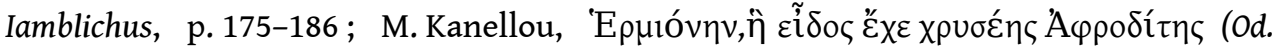
4.14): Praising a Female through Aphrodite - From Homer into Hellenistic Epigram, p. 189204 ; K. Arafat, Pausanias and Homer, p. 205-213 ; M. Ypsilanti, The Reception of Homeric Vocabulary in Nonnus' Paraphrase of St. John's Gospel: Examination of Themes and Formulas in Selected Passages, p. 215-224 ; A.N. Michalopoulos, Homer in Love: Homeric Reception in Propertius and Ovid, p. 289-300 ; R. Maltby, Homer in Servius: A Judgement on Servius as a Commentator on Virgil, p. 303-314 ; I. Petrovic, On Finding Homer: The Impact of Homeric Scholarship on the Perception of South Slavic Oral Traditional Poetry, p.315-327; K. Mikellidou, Aeschylus reading Homer: The Case of the Psychagogoi, p. 331-341 ; D.J. Jacob, Symbolic Remarriage in Homer's Odysseus and Euripides' Alcestis, p. 343-353 ; I. Karamanou, Euripides' 'Trojan Trilogy' and the Reception of the Epic Tradition, p. 355-367; V. Georgopoulou, Andromache's Tragic Persona from the Ancient to the Modern Stage, p. 369377 ; K. Petrakou, Odysseus Satirical: The Merry Dealing of the Homeric Myth in Modern Greek Theatre, p. 379-389. EIDINOW Esther, KINDT Julia, OSBORNE Robin (éd.), Theologies of Ancient Greek Religion, Cambridge, Cambridge University Press, 2016 (Cambridge Classical Studies).

E. Eidinow, J. Kindt, R. Osborne, S. Tor, Introduction: what might we mean by the theologies of ancient Greek religion?, p. 1-11 j. Kindt, The story of theology and the theology of the story, p. 12-34 ; B. Graziosi, Theologies of the family in Homer and Hesiod, p. 35-61 ; R. Gagné, Who's afraid of Cypselus? Contested theologies and dynastic dedications, p. 62-88;S. Tor, Heraclitus on Apollo's signs and his own: contemplating oracles and philosophical inquiry, p. 89-116; E. Csapo, The 'theology' of the Dionysia and Old Comedy, p. 117-152;S. Goldhill, Polytheism and tragedy, p. 153-175; H. Willey, Gods and men in ancient Greek conceptions of lawgiving, p. 176-204 ;E. Eidinow, Popular theologies: the gift of divine envy, p. 205-232; R. Osborne, Sacrificial theologies, p. 233-248;M. Gaifman, Theologies of statues in Classical Greek art, p. 249-280 ;G. Martin, The gods in the Athenian assembly, p. 281-300;R. Benitez, Plato and the secularisation of Greek theology, p. 301-316;G. Boys-Stones, Providence and religion in Middle Platonism, p.317-338;P. van Nuffelen, Narratives of continuity and discontinuity, p. 339-357.

fantuzZi Marco, TSAgalis Christos (éd.), The Greek Epic Cycle and Its Ancient Reception. A Companion, Cambridge, Cambridge University Press, 2015. 
M. Fantuzzi, Ch. Tsagalis, Introduction: Kyklos, the Epic Cycle and Cyclic poetry, p. 1-40; J. Burgess, Coming adrift: The limits of reconstruction of the cyclic poems, p. 43-58;G. Nagy, Oral traditions, written texts, and questions of authorship, p. 59-77 ;J.M. Foley, J. Arft, The Epic Cycle and oral tradition, p. 78-95 ; M.L. West, The formation of the Epic Cycle, p. 96-107 ; W. Kullmann, Motif and source research: Neoanalysis, Homer, and Cyclic epic, p. 108-125 ; M. Finkelberg, Meta-Cyclic epic and Homeric poetry, p. 126-138; Th. H. Carpenter, The Trojan War in early Greek art, p. 178-195 ; G. D'Alessio, Theogony and Titanomachy, p. 199212 ;E. Cingano, Oedipodea, p. 213-225 ;J.B. Torres-Guerra, Thebaid, p. 226-243 ; E. Cingano, Epigonoi, p. 244-260 ;A. Debiasi, Alcmeonis, p. 261-280 ; B. Currie, Cypria, p. 281-305;A. Rengakos, Aethiopis, p. 306-317;A. Kelly, Ilias parva, p. 318-343 ; P.J. Finglass, Iliou persis, p. 344-354;G. Danek, Nostoi, p. 355-379;Ch. Tsagalis, Telegony, p. 380-401; M. Noussia-Fantuzzi, The Epic Cycle, Stesichorus, and Ibycus, p.430-449; I. Rutherford, Pindar's Cycle, p. 450-486 ;A.H. Sommerstein, Tragedy and the Epic Cycle, p. 487-495 ;M. Squire, Running rings round Troy: Recycling the ,Epic Circle' in Hellenistic and Roman art, p. 496-542;U. Gärtner, Virgil and the Epic Cycle, p. 543-564 ;G. Rosati, Ovid and the Epic Cycle, p. 565-577;Ch. McNelis, Statius' Achilleid and the Cypria, p. 578-595; D.F. Elmer, The Epic Cycle and the ancient novel, p. 596-603 ; S. Bär, M. Baumbach, The Epic Cycle and imperial Greek epic, p. 604-622.

FAULKNER Andrew, VERgados Athanassios, schwab Andreas (éd), The Reception of the Homeric Hymns, Oxford, Oxford University Press, 2016.

J. Strauss Clay, Visualizing Divinity: The Reception of the Homeric Hymns in Greek Vase Painting, p. 29-51; J.J.Clauss, The Hercules and Cacus Episode in Augustan Literature: Engaging the Homeric Hymn to Hermes in Light of Callimachus' and Apollonius' Reception, p. 55-78 ; St. Harrison, The Homeric Hymns and Horatian Lyric, p. 79-94 ; J.F. Miller, Ovid's Bacchic Helmsman and Homeric Hymn 7, p. 95-108; A. Keith, The Homeric Hymn to Aphrodite in Ovid and Augustan Literature, p. 109-125 ; J.S. Nethercut, Hercules and Apollo in Ovid's Metamorphoses, p. 127-141 ; P. Strolonga, The Homeric Hymns Turn into Dialogues: Lucian's Dialogues of the Gods, p. 145-164 ; A. Vergados, The Reception of the Homeric Hymns in Aelius Aristides, p.165-186; J.B.Torres, The Homeric Hymns, Cornutus, and the Mythological Stream, p. 187-202 ; R.M. van den Berg, The Homeric Hymns in Late Antiquity: Proclus and the Hymn to Ares, p. 203-219; G. Agosti, Praising the God(s): Homeric Hymns in Late Antiquity, p.221-240 ; Ch. Simelidis, On the Homeric Hymns in Byzantium, p. 243-260; O. Thomas, Homeric and/or Hymns: Some Fifteenth-century Approaches, p. 277-299; M.E. Schwab, The Rebirth of Venus: The Homeric Hymns to Aphrodite and Poliziano's Stanze, p. 301-323 ; N. Richardson, 'Those miraculous effusions of genius': The Homeric Hymns Seen through the Eyes of English Poets, p. 325-344 ; A. Schwab, The Reception of the Homeric Hymn to Demeter in Romantic Heidelberg : J.H. Voss and 'the Eleusinian Document', p. 345-366.

FEJFER Jane, MOLTESEN Mette, RATHJE Annette (éd.), Tradition. Transmission of Culture in the Ancient World, Copenhagen, Collegium Hyperboreum and Museum Tusculanum, 2015 (Acta Hyperborea, 14).

C. Brøns, Textiles and Temple Inventories: Detecting an Invisible Votive Tradition in Greek Sanctuaries in the Second Half of the First Millenium BC, p. 43-83 ; S. Hansen, Using Textiles to Propose a New Identity for the So-Called Goddess of Xeste 3, p. 117-130 ; S. Isager, On a List of Priests: From the Son of Poseidon to Members of the Elite in Late Hellenistic Halikarnassos, p.131-148 ; A. Karivieri, Tradition and Renewal: The Archaeology of Magic and Theurgy in Athens and Rome in Late Antiquity, p. 181-194 ; J. Krasilnikoff, Tradition and Innovation in Classical Athens: The Case of the Athenian Acropolis as Place and History, p.195-212; 
E. Mortensen, Ktistes: Mythical Founder Hero and Honorary Title for New Heroes, p. 213-237 ; M. Nielsen, New Times, Old Costumes: Tradition and Renewal of Etruscan Funerary Culture from the Late Republic to the Early Empire, p. 269-299 ; R. Raja, Palmyrene Funerary Portraits in Contexts: Portrait Habit between Local Traditions and Imperial Trends, p. 329-361; St. Schierup, The Nestorides: Innovation and Ambivalence in the Early South Italian Red-Figure Production, p. 387-425 ; L.W. Sørensen, Here There be Monsters: Hybrids Painted on Cypriot Iron Age Pottery, p. 427-450; K. Winther-Jacobsen, Ceramics in Funerary Traditions in Hellenistic Cyprus: The Custom of Duplication ?, p. 481-493.

FISCHER Josef (éd.), Der Beitrag Kleinasiens zur Kultur- und Geistesgeschichte der griechisch-r ömischen Antike.Akten des Internationalen Kolloquiums (Wien, 3.-5. November 2010), Wien, Verlag der Österreichischen Akademie der Wissenschaften, 2014 (Österreichische Akademie der Wissenschaften. Denkschriften der phil.-hist. Klasse 469 ; Ergänzungsbände zu den Tituli Asiae Minoris, 27 ; Archäologische Forschungen, 24).

R. Fabiani, Gli onori dei prosseni a Iasos, p. 99-123 ;K. Harter-Uibopuu, Tote soll man ruhen lassen... Verbote und Strafen zur Sicherung von Gräbern am Beispiel von Inschriften aus Ephesos,

p. 157-180 ;

G. Hölbl,

Ägyptisches Kulturgut in Ionien im 7. Jh. v. Chr.: Der Beitrag Milets zu einem religionshistorischen Phänomen , p. 181-209 ; F. Kolb, Lykien, Lykier, Termilen in der frühen griechischen Literatur: ihr Beitrag zu griechischem Mythos und Historie, p. 257-277; M. Meyer, Tradition und Rezeption, Eigenart und Teilhabe: Gottheiten und ihre Bilder im griechisch-römischen Kleinasien, p. 279294 ; G. Petzl, Leben abseits der Zentren - Religion und Kultur im ländlichen Lydien, p. 301307 ; J. Stauber, Das Ida-Gebirge: Adaptionen einer mythischen Landschaft nebst Lokalisierungsfragen, p. 343-350.

FOUQUET Johannes, GAITANOU Lydia (éd), Im Schatten der Alten? Ideal und Lebenswirklichkeit im römischen Griechenland. 3. Heidelberger Altertumswissenschaftliches Studierendenkolloquium, 8.-10. November 2013, Mainz/Ruhpolding, 2016 (Peleus, 71).

F. Camina, The theoi Sebastoi in the sacred landscape of the polis. Cult places for the emperors in the cities of mainland Greece, p.9-23; F. Klauser, Altbekanntes neu kombiniert - Die Kistophoren der sog. Kleinen Propyläen in Eleusis, p. 143-158; J. Mätzschker, Frühe Kaiserkultstätten in den Provinzen Achaia, Epirus und Macedonia, p. 159-170 ; C. Parigi, Die Entwicklung des Kerameikos innerhalb und außerhalb der Befestigungsmauern zwischen dem 1. Jh. v. Chr. und dem 1. Jh. n. Chr., p. 171-186.

31 FREDERIKSEN Rune, GEBHARD Elizabeth R., SOKOLICEK Alexander (éd.), The Architecture of the Ancient Greek Theatre. Acts of an International Conference at the Danish Institute at Athens (2730 January 2012) Aarhus, Aarhus University Press, 2015 (Monographs of the Danish Institute at Athens, 17).

Ch. Papastamati-von Moock, The Wooden Theater of Dionysos Eleuthereus in Athens: Old Issues, New Research, p. 39-79; Ch. Wilkening-Aumann, The Hellenistic Theatre in the Sanctuary of Hemithea at Kastabos (Asia Minor): New Evidence and Reconstruction, p. 233251 ; D. Scahill, The 'South Building' in the Main Urban Sanctuary of Selinunte: A Theatral Structure?, p. 279-292. GARCíA RAMÓN José Luis (éd.), Epitheta deorum, Milano, 2014 (Aevum Antiquum 14, n.s.)

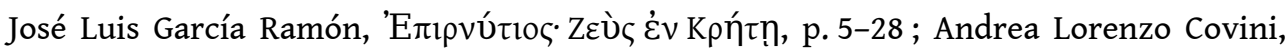
L'Artemide 'dei cervi' e 'dell'Alfeo' in Elide, p. 29-49; Clara Felisari,

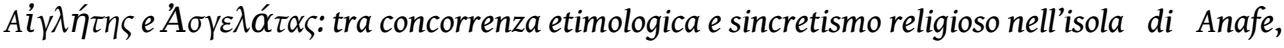




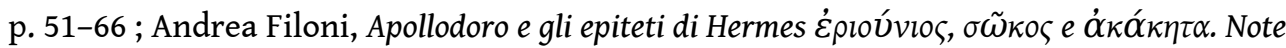
al testo di Cornuto, Comp. 16.3 e Ap. Soph. s.v. $\sigma \tilde{\omega} \kappa o \varsigma(148,15-22$ Bekker), p. 67-93; Elena Langella, Hera $\theta \varepsilon \lambda \xi \dot{\xi} v \eta$ (SEG 26 : 1211) e altri incantatori: epitheta deorum in $\theta \varepsilon \lambda \xi l-$, p. 95-118;

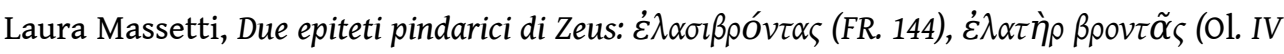
1), p. 119-130 ; Matilde Serangeli, Atena A łıótolvos (Paus. III 15, 6), p. 131-141.

GASPARINI Valentino (éd.), Vestigia. Miscellanea di studi storico-religiosi in onore di Filippo Coarelli nel suo $80^{\circ}$ anniversario , Stuttgart, Steiner, 2016 (Potsdamer Altertumswissenschaftliche Beiträge, 55).

Giovanna Battaglini, Su alcuni aspetti relativi ad Ercole e il sale nelle origini di Roma, p. 51-64 ; S. Sisani, Il concetto di pomerium. Valenza giuridicosacrale e realtà topografica dei fines Urbis, p. 65-80;F. Diosono, La porta e il porto. Il culto di Portunus nella Roma arcaica e repubblicana, p. 81-98 ; M. Cébeillac-Gervasoni, Neptune, Rome, Véies et le lac Albain, p. 99106 ; P. Braconi, Dall'aes piscatorium all'anulus piscatoris. Vulcano, i pesci e il romanzo del fuoco nell'acqua, p. 107-118; G. Ghini, Boschi sacri e ritualità. Il caso del lucus Dianae in nemore aricino, p. 119-130;S. Gatti, Culti e luoghi di culto pre-romani nel Lazio meridionale interno, p. 131-143; ;. Leggio, 'Ubi putentes aquae emanant et sulphureae'. Cotilia da luogo di culto di acque salutari a scenario per il martirio di san Vittorino, p. 145-156;E. Greco, Apollo e Afrodite ai confini occidentali della chora ateniese, p. 159-172;M. Maiuro, Scoping early Rome. Coarelli, the 'Numan calendar' and the feriae conceptiuae, p. 173-188; R.E. Tébar, L'origine del culto di Cerere nella villa di Plinio il Giovane in Tuscis, p. 189-201; J. Scheid, Le lustrum et la lustratio. En finir avec la 'purification', p. 203-209;M. R. Picuti, Il tempio a doppia cella in località 'Nocette di Pale' (Foligno, PG), p. 211-221;O. de Cazanove, L'autel à cour de Rossano di Vaglio. Une analyse de son usage, p. 223-238; P. Gros, La sémantique sacrale du marbre blanc à Rome de la fin de la République à l'époque augustéenne, p. 239-252; M.H. Crawford, Chalcedon, Marcian and the XII Tablets, p. 253-256; M. Torelli, Venus Troiana. L'Afrodite 'tipo Tiepolo', gli Aemilii e il fregio della Basilica Emilia, p. 259-272 ;L. Pedroni, Interdizione religiosa e lotta politica. Il caso dei denari di Fabius Pictor e Postumius Albinus, p. 273-279; H. Uroz Rodríguez, J. Uroz Sáez, Imagen divina, vaso ritual, mito aristocrático. La diosa y el príncipe ibero de Libisosa, p. 281-294 ;F. Zevi, Honos a Puteoli. In margine alla 'lex parieti faciundo', p. 295-314 ;A. Dubourdieu, Le savoir des augures comme interpretes Iovis chez Cicéron (De legibus, De natura deorum, De divinatione), p. 327-336 ;C. Pavolini, Ancora sui culti orientali a Roma. Dagli hymnologi di Cibele alle nuove ipotesi topografiche, p. 337-348; D. Nonnis, Appunti sugli ex-voto fittili con iscrizione dall'Italia repubblicana. A proposito di una dedica medio-repubblicana da Cales, p. 349-366 ;S. Panciera, CIL VI 8, 1. Inscriptiones sacrae. Fragmenta, II, p. 367-380 ;J. Mangas, Mujeres, libertos y esclavos de Hispania devotos de Marte, p. 381-391;C. Gonzáles Román, Religión e iconografía en la Colonia Iulia Gemella Acci, p. 393-406 ;R. Rubio Rivera, Consideraciones en torno al mitraísmo en Umbría, p. 407-419; H. Solin, Silvano oscuro, p. 421-436 ; W.V. Harris, Religion on the battlefield. From the Saxa Rubra to the Frigidus, p. 437-450;L. Agostiniani, Non uno ma due. Qualche considerazione sull'onomastica divina etrusca, p. 453-466 ;E. Jarva, Zeus from the Cape Artemision shipwreck, p. 467-476;A. Celani, A marble head from Terracina. Sculpture and religion in ancient Latium and Greece, p. 477-490;I. Bragantini, Una singolare rappresentazione di Giove da Ercolano, p. 491-502 ;E. Lo Sardo, Immagini dell'universo nel mondo ellenico, p. 505-516;A. Polosa, Monete e culti a Sibari e a Thurii, p. 517-526;M. Clavel-Lévêque, Les avatars des dieux gaulois et la colonie romaine de Béziers (Hérault, France), p. 526-540;F. Marcattili, Il giuramento di Marsia, p. 541-554;V. Gasparini, Listening stones. Cultural appropriation, resonance, and memory in the Isiac cults, p. 555-574 ;E.M. Steinby, Fra il sacro e il profano. 
Immagini nei bolli doliari centro-italici, p. 603-615 ;A.M. Poveda Navarro, Un ejemplo de sincretismo religioso de la antigüedad. Hércules Cristo en la Hispania tardo-antigua, p. 617-630 ;M. Nafissi, Oreste, Tisameno, gli Ephoreia e il santuario delle Moire a Sparta, p. 633-644 ; Th. Mavrojannis, The 'Great Tumulus' at Amphipolis. Remarks on its chronology in comparison to the debate for the 'deification' of Hephaestion, p. 645-662;L. Alapont Martín, La necrópolis samnita de Alife. Estudio antropológico y de los gestos y ritos funerarios, p. 663-674;P. Vitti, Il Mausoleo di Adriano e il culto dinastico. L'evidenza architettonica, p.675-688;V. Tsiolis, Antínoo en Mantinea, p. 689-699 ;E. De Albentiis, La (presunta) sacralità dell'antico. Alcuni esempi comparati nei mutamenti toponomastici dell'Italia post-unitaria e fascista, p. 703-713 ; A. Tinterri, Quel che resta di Edipo, p. 715-726 ; L. Romagnoli, G. Batocchioni, Allestimenti e restauri di antichi luoghi sacri. Un motivo di studio per la restituzione di un'immagine compiuta, p. 727-740 ;A. Schnapp, Une stratégie de l'universel. La fondation de la culture islamique et les ruines, p. 741-749.

GEBHARD Elizabeth R., GREGORY Timothy E. (éd.), Bridge of the Untiring Sea. The Corinthian Isthmus from Prehistory to Late Antiquity, Princeton, The American School of Classical Studies at Athens, 2015 (Hesperia, suppl. 48).

F.P. Hemans, The Archaic Temple of Poseidon: Problems of Design and Invention, p. 39-63 ; M.K. Risser, City, Sanctuary, and Feast: Dining Vessels from the Archaic Reservoir in the Sanctuary of Poseidon, p. 83-96 ; L. Houghtalin, The Temple Deposit at Isthmia and the Dating of Archaic and Early Classical Greek Coins, p. 97-108; A. Thomsen, Riding for Poseidon: Terracotta Figurines from the Sanctuary of Poseidon, p.109-118; M.C. Sturgeon, New Sculptures from the Isthmian Palaimonion, p.159-192; J. Wiseman, Agonistic Festivals, Victors, and Officials in the Time of Nero: An inscribed Herm from the Gymnasium Area of Corinth, p.193-246; F.K. Yegül, Roman Baths at Isthmia and Sanctuary Baths in Greece, p. 247-269 ; St.J.R. Ellis, E.E. Poehler, The Roman Buildings East of the Temple of Poseidon on the Isthmus, p. 271-287.

HAWES Greta (éd.), Myths on the Map. The Storied Landscapes of Ancient Greece, Oxford, Oxford University Press, 2017.

Greta Hawes, Of Myths and Maps, p. 1-13;Katherine Clarke, Walking through History: Unlocking the Mythical Past, p.14-31; Daniel W.Berman, Cities-Before-Cities: 'Prefoundational' Myth and the Construction of Greek Civic Space, p. 32-51; Richard Buxton, Landscapes of the Cyclopes, p.52-64; Elizabeth Minchin, Mapping the Hellespont with Leander and Hero: 'The Swimming Lover and the Nightly Bride', p.65-82 ; Emma Aston, Centaurs and Lapiths in the Landscape of Thessaly, p. 83-105; Stephanie Larson, Meddling with Myth in Thebes: A New Vase from the Ismenion Hill (Thebes Museum 49276), p. 106-121 ; Jeremy McInerney, Callimachus and the Poetics of the Diaspora, p. 122-140 ; Julie Balériaux, Pausanias'Arcadia between Conservatism and Innovation, p. 141-158 ; Christina A. Salowey, Rivers Run Through It: Environmental History in Two Heroic Riverine Battles, p. 159-177; Betsey A. Robinson, Fountains as Reservoirs of Myth and Memory, p. 178-203 ; Aara Suksi, Scandalous Maps in Aeschylean Tragedy, p. 204-220 ; Iris Sulimani, Imaginary Islands in the Hellenistic Era: Utopia on the Geographical Map, p. 221-242 ; Robert. L. Fowler, Imaginary Itineraries in the Beyond, p. 243-260; Charles Delattre, Islands of Knowledge: Space and Names in Imperial Mythography, p. 261-280 ; Richard Hunter, Serpents in the Soul: The 'Libyan Myth' of Dio Chrysostom, p. 281-298.

HOZ (DE) María-Paz, SÁNCHEZ HERNÁNDEZ Juan Pablo, MOLINA VALERo Carlos (éd.), Between Tarhuntas and Zeus Polieus: Cultural Crossroads in the Temples and Cults of Graeco-Roman Anatolia, Leuven, Peeters, 2016 (Colloquia Antiqua, 17). 
Robert Parker, 'For Potamos, a Vow': River Cults in Graeco-Roman Anatolia, p. 1-13 ; Carlos Molina Valero, What do we know about the Letoon? A Study of a Sanctuary during the Period of Achaemenid Rule over Lycia, p. 15-45; Luis Ballesteros-Pastor, Comana Pontica in Hellenistic Times: A Cultural Crossroads, p. 47-73 ; Christina G. Williamson, A Carian Shrine in a Hellenising World: The Sanctuary of Sinuri, near Mylasa, p. 75-99; Mustafa H. Sayar, The Temple on Uzunoğlan Hill in Smooth Cilicia, p. 101-116; Aitor Blanco-Pérez, Mên Askaenos and the Native Cults of Antioch by Pisidia, p.117-150; Marijana Ricl, The Cult of Meis Axiottenos in Lydia, p. 151-169; Hasan Malay, Cumur Tanriver, The Cult of Apollo Syrmaios and the Village of Parloai near Saittai, North-Eastern Lydia, p. 171-184 ; María-Paz de Hoz, The Goddess of Sardis: Artemis, Demeter or Kore?, p.185-224; Juan Pablo Sánchez Hernández, Sipylene: The Mother Goddess of Mount Sipylus, p. 225-245.

HUYSECOM-HAXHI Stéphanie, MULLER Arthur (éd.), Figurines grecques en contexte. Présence muette dans le sanctuaire, la tombe et la maison, Villeneuve d'Ascq, Presses Universitaires du Septentrion, 2015 (Archaiologia).

M. Albertocchi, Shall We Dance? Terracotta Dancing Groups of the Archaic Period in the Aegean World, p. 13-24 ;A. Pautasso, La fille au pavot dans la coroplathie archaïque. Histoire et interprétations des relations symboliques, p. 25-34; V. Dasen, Des Patèques aux 'nains ventrus' : circulation et transformation d'une image, p. 35-51; V. Jeammet, Histoire de têtes au féminin. Fonction d'une catégorie particulière en Attique et Béotie (IV siècle), p. 53-70; St. Huysecom-Haxhi, Du coq au canthare. Images de l'initiation masculine dans la coroplathie béotienne à l'époque classique, p. 71-89; M. Chidiroglou, Female Figurines of Classical and Hellenistic Times from Euboea. An Exploration of their Votive and Funerary Uses, p. 91-106; A. Bellia, Triadi di suonatrici nella Sicilia e nella Calabria di età greca (IV-III sec. a.C.), p. 107126 ; A. Hermary, Une étude contextuelle des terres cuites de Délos est-elle possible ?, p. 127140 ; J.P. Uhlenbrock, Heirlooms, Aphidrumata, and the Foundation of Cyrene, p. 143-156 ; S. Huber, P. Maillard, Cavaliers et dédicantes: les terres cuites de l'Athénaion et la communauté civique d'Érétrie, p. 157-177 ; G. Salapata, Terracotta Votive Offerings in Sets or Groups, p.179-197; M.C. Marín Ceballos, A.M. Jiménez Flores, M. Belén Deamos, J.H. Fernández, F. Horn, A. Mezquida, Les terres cuites de la grotte d'Es Culleram (Ibiza, Espagne) : iconographie et fonction, p. 198-217; B. Muka, Figurines dans un lac: le cas de Seferan en Illyrie, p. 218-229; A. Schwarzmaier, Terrakotten in der Nekropole von Lipari, p. 233-243 ; N. Mathieux, Jouet, attribut ou symbole? ?e motif du raisin dans les figurines des tombes de Myrina, p. 245-263 ; F. Horn, Terres cuites funéraires, individualités et sociétés. L'exemple du monde ibérique (VI-II ${ }^{e}$ s. av. J.-C.), p. 265-287 ;S. de Larminat, Les figurines en terre cuite dans les nécropoles d'Afrique romaine, p. 289-303 ;St.A. Hagan, Nysiac Devotions: Woman-and-Child Figurines from Byzantine Burials at Beth Shean, p. 305-317 ;A.-L. Schallin, Defining a Cultic Context at the Mycenaean Potter's Workshop at Mastos (Berbati Valley) through the Assemblage of Figures and Figurines, p. 321-336;M. Vetters, From Discard Patterns to Enacted Rituals? Contextualizing Mycenaean Terracotta Figurines in Settlement Deposits, p. 337-360;H. Jackson, Domestic Cult or Culture? Figurine Fragments from a Hellenistic Housing Insula in North Syria, p. 385-400 ; C.E. Barrett, Terracotta Figurines and the Archaeology of Ritual: Domestic Cult in Greco-Roman Egypt, p. 401-419; St. HuysecomHahxi, A. Muller, Figurines en contexte, de l'identification à la fonction : vers une archéologie de la religion, p. 421-438.

KISTLER Erich, ÖHLINGER Birgit, MOHR Martin, HOERNES Matthias (éd.), Sanctuaries and the Power of Consumption. Networking and the Formation of Elites in the Archaic Western 
Mediterranean World. Proceedings of the International Conference (Innsbruck, 20th-23rd March 2012), Wiesbaden, Harrassowitz, 2015 (Philippika, 92).

M. Mauersberg, Obsolete Perceptions? Frameworks of Intercultural Exchange in Ancient Narrative, p. 3-19;V. Sossau, The Cultic Fingerprint of the Phoenicians in the Early Iron Age West?, p. 21-41;E. Pappa, Oriental Gods but Domestic Elites? Religious Symbolism and Economic Functions of Phoinician-Period Cult Loci in South Iberia, p. 43-62 ; P. Amann, Gaben unter Eliten. Zu den etruskischen mulu/muluvanice-Inschriften, p. 63-81;M. Steger, La Tomba dei Guerrieri a Montagna di Marzo alla luce della diffusione delle 'iscrizioni parlanti' in Sicilia dall'età arcaica alla prima metà del V sec. a.C., p. 83-97;Ch. Russenberger, Bildproduktion und gesellschaftliche Entwicklung der indigenen Kulturen West- und Zentralsiziliens in archaischer Zeit, p. 99-135 ; H. Baitinger, In weiter Ferne, so nah! Einheimisches und Fremdes im Spiegel der Metallfunde von Seliunt, p. 137-151; St. Vasallo, Ogetti in movimento in età arcaica e classica ad Himera, porto sicuro per uomini, merci, idee, p. 153-167 ; Y. Gönster, The Silphion Plant in Cyrenaica: An Indicator for Intercultural Relationships?, p. 169-184; M. Fabbri, A Seat of Power in Latium Vetus: The Archaic Building Complex on the Arx of Gabii, p. 187-203 ; L. Fiorini, The Sacred Area of Gravisca: Ethnic and Religious Interactions in Comparison, p. 205-219; M.P. Baglione, B. Belelli Marchesini, C. Carlucci, M.D. Gentili, L.M. Michetti, Pyrgi: A Sanctuary in the Middle of the Mediterranean Sea, p.221-237; S.M. Bertesago, V. Garaffa, Manifestazioni del sacro di età arcaica nella mesogaia della costa ionica. I depositi votivi di 'Grotte delle Fontanelle' a Garaguso, p. 239-261;A. Corretti, F. Cambi, L. Pagliantini, 'The Finest Harbour': The Argonauts (and the Others) on the Island of Elba, p. 263-274 ; M.C. Parra, Il santuario del Capo Cocinto: 'nuovo' osservatorio occidentale di presenze multiculturali, p. 275-286;F. Spatafora, Sanctuari e luoghi sacri in un'area di frontiera: la valle del Belice tra elimi, sicani, punici e greci, p. 287-301;M. de Cesare, Aspetti del sacro a Segesta tra l'età arcaica e la prima età classica, p. 303-324;C. Marconi, V. Tardo, C. Trombi, The Archaic Pottery from the Institute of Fine Arts Excavations in the Main Urban Sanctuary on the Akropolis of Selinunte, p.325-338;J. Bergemann, Drehscheiben der Kulturen? Ländliche Heiligtümer in Sizilien: Gela und Agrigent im Vergleich, p. 339-348 ; J.P. Crielaard, Powerful Things in Motion: A Biographical Approach to Eastern Elite Goods in Greek Sanctuaries, p. 351-372; M. Gleba, Sacred Cloth: Consumption and Production of Textiles in Sanctuaries and the Power of Elites in Archaic Western Mediterranean World, p. 373-383; E. Kistler, M. Mohr, Monte Iato: Two Late Archaic Feasting Places between the Local and the Global, p. 385-415 ;B. Öhlinger, Indigenous Cult Places of Local and Interregional Scale in Archaic Sicily: A Sociological Approach to Religion, p. 417-434 ;M. Osanna, Seats of Power and Power of Consumption in the Hinterland of the Ionian Coast of Southern Italy during the Archaic Age, p. 435-457;G. Zuchtriegel, Archaic Latin Sanctuaries: Ritual Consumption in the Mediterranean Context, p. 459-471;R. Graells i Fabregat, Zwischen Privatem und Öffentlichkeit. Das festliche Bankett als soziale Praxis in Katalonien im 6. Jahrhundert v. Chr., p. 473-486; H.P. Isler, Conclusione, p. 489-492;E. Kistler, B. Öhlinger, M. Hoernes, M. Mohr,Debating 'Sanctuaries and the Power of Consumption' - or: Eight Points to an Alternative Archaeology of Proto-Globalisation, p 493-540.

KYRIAKOU Poulheria, RENGAKOS Antonios (éd.), Wisdom and Folly in Euripides, Berlin/Boston, de Gruyter, 2016 (Trends in Classics. Supplementary volumes, 31).

G.O. Hutchinson, Gods wise and foolish: Euripides and Greek literature from Homer to Plutarch, p. 37-44 ;M.S. Mirto, 'Rightly does Aphrodite's Name begin with aphrosune': Gods and Men between Wisdom and Folly, p. 45-63 ;B. Goff, The Leopard-skin of Heracles: traditional wisdom and untraditional madness in a Ghanaian Alcestis, p. 347-364. 
Stuttgart, Steiner, 2016.

Ch. Mann, Sport im Hellenismus: Forschungsstand und Forschungsperspektiven, p. 17-29 ; Th. Heine Nielsen, Reflections on the Number of Athletic Festivals in Pre-hellenistic Greece, p. 31-41; O.M. van Nijf, Ch. G. Williamson, Connecting the Greeks: Festival Networks in the Hellenistic World, p. 43-71; B. Fauconnier, Athletes and Artists in an Expanding World. The Development of Ecumenical Associations of Competitors in the First Century BC, p. 73-93; Z. Papakonstantinou, The Hellenistic Agonothesia: Finances, Ideology, Identities, p. 95-112 ; E. Franchi, Sport and War in Hellenistic Sparta, p.113-130; M. Mathys, Athleten im Gymnasion von Pergamon, p. 131-152; A. Argyriou-Casmeridis, Victories and Virtues: The Epigraphic Evidence for Hellenistic Athletes as Models of arete, p.153-178; K. Weber, Athletendarstellungen in der hellenistischen Grabkunst - Überlegungen zum Stellenwert der Athletenrolle in der Polisgesellschaft, p. 179-207; S. Scharff, Das Pferd Aithon, die Skopaden

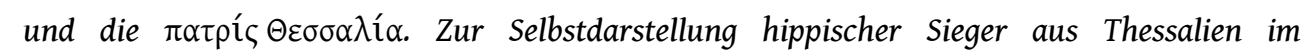
Hellenismus, p. 209-229 ; F. Daubner, Agone im hellenistischen Nordgriechenland, p. 231245 ; St. Sansom, Contests and Clothing in Four Agonistic Papyri from Hellenistic Egypt, p. 247-262 ; B. Dimde, Inszenierung von Läufern oder laufende Inszenierung - Stadien und Startvorrichtungen in hellenistischer Zeit, p. 263-287 ; F. Klauser, Zur Aufstellungspraxis von Standbildern siegreicher Athleten in Athen in hellenistischer Zeit, p. 289-314 ; L. Cazzadori, Callimachus on Agones and Athletes, p. 315-330 ; L. Kainz, 'We are the Best, We are One, and We are Greeks!' Reflections on the Ptolemies' Participation in the agones, p. 331-353.

MARTHARI Marisa, RENFREW Colin, BOYD Michael J. (éd.), Early Cycladic Sculpture in Context, Oxford/Philadelphia, Oxbow, 2017.

C. Renfrew, Early Cycladic sculpture: issues of provenance, terminology and classification, p. 112 ; M. Marthari, Early Cycladic sculptures as archaeological objects, p. 13-21 ; C. Renfrew, The sculptures of Neolithic Saliagos, p. 23-29; A.Sampson, V. Mastrogiannopoulou, Figurines from the Late Neolithic settlement of Ftelia, Mykonos, p. 30-38 ; Ch. A. Televantou, Figurines from Strofilas, Andros, p. 39-51; Ch. Doumas, Figurines from Akrotiri, Naxos and Plastiras, Paros, p. 53-64 ; J. Rambach, Schematic marble figurines from secure Early Cycladic I grave contexts on the islands of Ano Kouphonisi, Antiparos, Dhespotiko, Naxos, Paros and Siphnos, p. 65-87; Th. Papangelopoulou, A schematic figurine of shell from Mersinia on Kythnos, p. 88-92 ; D. Wilson, The Cycladic marble figurines from EBII Ayia Irini, Kea: evidence for ritual deposition in domestic contexts, p. 93-102; P. Pantou, A fragment of an Early Cycladic figurine from the prehistoric settlement at Plakalona on Seriphos, p. 103-106; Z. D. Papadopoulou, Sculptures from Akrotiraki, Siphnos and its cemetery, p.107-118; M. Marthari, Cycladic figurines in settlements: the case of the major EC II settlement at Skarkos on Ios, p. 119-160 ; Y. Maniatis, Appendix: non-invasive examination of marble figurines from Skarkos on Ios, p.161-164; C. Renfrew, The figurines from the settlement at Dhaskalio, p. 165-170 ; O. Philaniotou, Figurines from Potamia on Epano Kouphonisi (Pandelis Tsavaris property), p.171-182; Ch. Doumas, V. Lambrinoudakis, The cemetery at Aplomata on Naxos, p. 183-209; O. Philaniotou, Appendix: pottery from the cemetery of Aplomata, Naxos, p. 210-218 ; I. Legaki, Sculptures from Phiondas, Naxos, p. 219-254 ; Ch. Doumas, Sculptures from Aghioi Anargyroi and Avdeli, Naxos, p. 255-262; 0. Philaniotou, Figurines from the cemetery of Tsikniades, Naxos, p. 263-271; G. Gavalas, Marble figurines from sites on Epano and Kato Kouphonisi, p. 272-296; M. Marthari, Figurines in context at the Chalandriani cemetery on Syros, p. 297-307 ; Y. Maniatis, Appendix: non-invasive examination of marble objects from Chalandriani, Syros, p. 307-309 ; L. Papazoglou-Manioudaki, The Early Cycladic

Kernos, 30 | 2017 
figurines from the excavations of Clon Stephanos on Syros and a note on his work on Naxos: towards context, p. 310-331 ; D. Tambakopoulos, Y. Maniatis, Appendix: optical examination of fourteen Cycladic figurines from Syros, p. 331-334; Ph. Zapheiropoulou, The complete canonical sculpture of Spedos variety from Dhaskalio Kavos on Keros, p. 335-344; P. Sotirakopoulou, C. Renfrew, M.J. Boyd, Selected sculptural fragments from the Special Deposit North at Kavos on Keros, p. 345-368; C. Renfrew, The figurine fragments recovered from the Special Deposit North at Kavos in 1987, p. 369-372; G. Gavalas, The stone vessels found at Dhaskalio Kavos in 1987, p. 373-378; C. Renfrew, M.J. Boyd, Selected sculptural fragments from the Special Deposit South at Kavos on Keros, p. 379-394 ; J. Haas-Lebegyev, Marble and other spools from the excavations at Dhaskalio and the Special Deposit South at Kavos, Keros, p. 395-407 ; St. Katsarou, D.U. Schilardi, Recontextualised Neolithic and Early Cycladic figurines at the acropolis of Koukounaries, Paros, p. 409-420 ; C.R. Hershenson, J.C. Overbeck, Early Cycladic figurines in later contexts at Ayia Irini, Kea, p. 421-435; C. Renfrew, M.J. Boyd, The marble sculptures from Phylakopi on Melos, p. 436-445; Ch. Doumas, Early Cycladic sculptures from the settlement at Akrotiri, Thera, p. 446-454; R.L.N. Barber, Terracotta figurines from Mikre Vigla, Naxos, p. 455-465 ; D. Tambakopoulos, Y. Maniatis, The marble of the Cyclades and its use in the early Bronze Age, p. 467-482; Y. Papadatos, E. Venieris, An experimental approach to the manufacture of Cycladic-type figurines with folded arms : preliminary observations, p. 483-490; K. Birtacha, Examining the paint on Cycladic figurines, p. 491-502.

MARTín-Velasco María José, García Blanco María José (éd.), Greek Philosophy and Mystery Cults, Newcastle upon Tyne, Cambridge Scholars Publishing, 2016.

F. Casadesús, The Transformation of the Initiation Language of Mystery religions into Philosophical Terminology, p.1-26; A. Bernabé, Aristotle and the Mysteries, p. 27-42; A. De Castro Caeiro, Eschatological Myth in Plato's Gorgias, p. 43-60 ; M.R. Gómez Iglesias, The Echoes of Eleusis: Love and Initiation in the Platonic Philosophy, p. 61-102; F. Blanco Rodríguez, The Influence of Orphism in Plato's Psychology and Eschatology, p. 103-121; A. Bordoy Fernández, Proclus and the Role of Orphism in the Exegesis of Plato's Timaeus, p.123-147; J. de Garay, Mystery Religions and Philosophy in Proclus, p. 149-170; M.J. Hermoso Felix, Philosophy and Theurgy in the Thought of Iamblichus: Symbol and Beauty, p. 171-185 ; A. Navarro González, The Dionisism in the Bacchae: Megála kài Phanerá, p. 187-204 ; M.A. Santamaría Álvarez, Did Plato Know the of the Orphic God Protogonos?, p. 205-226.

MULLER Arthur, LAFLI Ergün (éd.), Figurines de terre cuite en Méditerranée grecque et romaine. Volume 2: Iconographie et contextes, Villeneuve d'Ascq, Presses Universitaires du Septentrion, 2015 (Archaiologia).

L.C. Bournias, A New Ionian Kouros Terracotta Figurine from the Temple of 'Athena' at Karthaia (Keos Island), p. 23-30 ; J.P. Uhlenbrock, A New Herakles Type and Archaic, East Greek Terracottas at the Extramural Sanctuary of Demeter and Persephone at Cyrene, Libya, p. 31-39 ; J. Kozlowski, Les figurines d'hydrophores: milieu(x) et signification(s), p. 41-48; M. Deoudi, Bendis in Kleinasien, p. 49-59; E. Dereboylu-Poulain, Les reliefs au cavalier de Neon Teichos (Éolide), p. 61-65 ; N. Mathieux, Les sirènes de Myrina, p. 67-82 ; C. LangAuinger, Männliche Puppen aus Ephesos, p. 83-93 ; D.S. Akar Tanriver, Bull/Bovine Figurines from the Sanctuary of Apollo Clarius (Ionia), p. 125-136; M.R. Ciuccarelli, L'usage religieux des vases plastiques de la Grèce de l'Est en Sicile, Grande Grèce et Étrurie: le cas de la tête d'Acheloos, p. 145-148 ; V. Sabetai, Female Protomes from Chaeroneia (Boeotia), p. 149-163; K. Tzanavari, Protomés de terre cuite de l'antique Lètè (Mygdonie), p. 165-179; A. Bellia, 
Terracotta Female Musicians from the Sanctuary of Fontana Calda (Sicily), p.181-188; N. Martin, Les danseuses voilées au IV ${ }^{e}$ s. av. J.-C., p. 189-194 ;C.E. Barrett, Harpocrates on Rheneia. Two Egyptian Figurines from the Necropolis of Delos, p. 195-208;J.-L. Podvin, Figurines isiaques en terre cuite d'Asie Mineure, p. 209-217 ;S. Japp, H. Schwarzer, Figürliche Terrakotten aus zwei dionysischen Kultgebäuden in Pergamon, p. 249-265 ;M. Kosma ( $\dagger$ ), A Group of Terracotta Figurines from Samos: a Case for a Domestic Cult?, p. 281-287 ;0. Mariaud, Formes et fonctions des terres cuites dans les tombes archaïques de Samos, p. 297-304; A. Schwarzmaier, Gaben für eine nicht erlebte Hochzeit. Zu Funktion und Bedeutung einiger Terrakottentypen in klassischen Mädchengräbern in Athen, p. 305-315;A. Harami, V. Jeammet, Les figurines de la tombe B 158 de Thèbes : Tanagréennes ou Thébaines ?, p. 317331 ;M. Bonanno Aravantinos, La tomba 404 della necropoli nordorientale di Tebe (Beozia), p. 333-348;A. Alexandropoulou, Terracotta Figurines from Cemeteries of Chaironeia in North Boeotia, p. 349- 355 ;M. Selekou, Animal Terracottas from Children Graves at Opuntian Locris, p. 357-364 ;P. Malama, Terrakotten aus der östlichen Nekropole von Amphipolis, p. 365-374 ; V. Tolun, Terracotta Figurines from the Western Necropolis of Assos, p. 375-384;C. Kozanli, Trois tombes d'enfants de la nécropole de Parion, p. 385-398; A. F. Ferrazzoli, Statuine di terracotta da tombe rupestri in Elaiussa Sebaste (I sec. a.C.-II sec. p.C.), p. 399-404; Th. Kopestonsky, Cueing Behaviour. Figurines in Small Shrines at Corinth, p. 407-416; A. Barakari-Gleni, Terracotta Votives from an Archaic Sanctuary in Argos, p. 417-424; A. Nagel, Down-to-Earth in Arcadia. Terracotta Figurines from a Sanctuary of Demeter and Kore in Tegea, p. 425-430 ;A. Vassiliki Karapanagiotou, I. Leventi, The Terracotta Figurines from the Haghios Sostis Sanctuary at Tegea, p. 431-436 ;M.G. Spathi, Votive Terracottas in Sanctuaries of Ancient Messene. Recent Finds and Cult Practices, p.437-448;A. Nagel, Retrospectives and Perspectives. Terracotta Figurines from a Votive Deposit in Stratos (Akarnania), p. 449-456;I. Svana, Votive Terracotta Figurines from a Rural Sanctuary in Thesprotia, Epirus, p. 457-463 ;S. Samartzidou-Orkopoulou, Drakospilia : une grotte cultuelle aux confins occidentaux de Céphalonie, p. 465-472;V. Vassilopoulou, N. Skoumi, E. Nassioti, Aphrodite Figurines from the sanctuary of 'Nymph Koronia' at Mount Helicon, p. 473-480 ; A. Duplouy, A. Zambon, Des terres cuites pour Déméter. Observations sur la petite plastique du sanctuaire de Vamies (Itanos, Crète), p. 481-486; E. Simantoni-Bournias, Enthroned Goddesses from the Sanctuary of Hyria on Naxos, p. 487-494;M. Dewailly, U. Muss, L'Artémision d'Éphèse.Les offrandes en terre cuite de l'époque archaïque, p. 497-514; E. Doran Gürbüzer, Visiting Goddesses? Female Deities in the Sanctuary of Apollo at Claros, p. 515-521; L. Karlsson, Terracotta Figurines from Labraunda (Caria). A Brief Note, p. 523-527 ;F. Berti, Appunti su alcuni tipi di statuette ritrovate nel Thesmophorion di Iasos, p.529-536; M. Çekilmez, Archaic Terracottas from the Louis Robert Excavations at Amyzon, p. 537-540 ; S. Picaud, Au Létoon de Xanthos: cavaliers ou orantes ?, p. 541-545;W. Wamser-Krasznai, M. Recke, Aphrodite auf der Akropolis von Perge? Terrakottastatuetten aus F1, p. 547-553; G. Iàin, Terracotta Figurines from Arpalðk Tepe in Pisidia: Apollo and the Great Mother Goddess in a Cave Sanctuary, p. 555-570; L. Summerer, Bulls and Men on the Mountaintop. Votive Terracottas from ÇiriÀli Tepe (Central Black Sea), p.571-586; D. Leibundgut Wieland, Tonstatuen und -statuetten der paphischen Göttin aus dem Heiligtum der Aphrodite in AltPaphos auf Cypern, p. 589-603 ;T. Ilyina, Terracotta Protomes from the Sanctuary on Maiskaya Mount (Asian Bosporos), p. 605-612 ;J.-S. Caillou, Un lot de figurines grecques découvert à Apollonia de Cyrénaïque, p. 613-616.

osADA Toshihiro (éd.), The Parthenon Frieze. The Ritual Communication between the Goddess and the Polis. Parthenon Project Japan 2011-2014, Wien, Phoibos, 2016. 
T. Osada, The Parthenon Frieze - Display of Piety and Privilege, p. 11-30 ;A. Moroo, The Origin and Development of the Acropolis as a Place for Erecting Public Decreed: The Periclean Building Project and Its Effect on the Athenian Epigraphic Habit, p. 31-48;R. Nakamura, A 3D Recreation of the Gods on the Parthenon Frieze. The Bodies and Space of the 'Invisibles', p. 49-59 ;T. Nakamura, The Clothing and Armour of the Horsemen and Warriors on the Parthenon Frieze, p. 61-82 ;M. Sakurai, The Peplos Scene of the Parthenon Frieze and the Citizenship Law of Perikles, p. 83-90;Ch. Shinozuka, Myth and Ritual. The Garments of the Maidens on the Parthenon East Frieze, p. 91-117 ;E. Tanaka, The Concept of Space in the Parthenon Frieze, p. 119-138 ;A. Mizuta, Looking at the Parthenon East Frieze with Jacques Carrey, p. 139-169.

PATAY-HORVATH András(éd.), New Approaches to the Temple of Zeus at Olympia. Proceedings of the First Olympia-Seminar 8th-10th May 2014, Newcastle upon Tyne, Cambridge Scholars Publishing, 2015.

A. Patay-Horváth, Introduction. Adopting a New Approach to the Temple and its Sculptural Decoration, p.1-14; A. Hennemeyer, The Temple Architecture and its Modifications during the 5th Century BCE, p. 16-38; U. Weber, Versatzmarken auf Baugliedern des Zeustemples von Olympia, p.39-55; W. Sonntagbauer, Metrologisches in Olympia, p.56-71; O. Palagia, Dating the Corner Figures of the West Pediment and Questions Arising from the Use of Parian and Pentelic Marbles in the Sanctuary, p. 74-89 ; T. Hölscher, Noch einmal rechts und links am Zeus-Tempel von Olympia, p.90-93; A. Patay-Horváth, An der linken Seite des großen Tempels (Paus. 5.26.2), p. 94-97; T. Osada, The invisible God: The Representation of Divine Intervention in the Early Classical Period, p. 98-109; J. Taita, The Great Hecatomb to Zeus Olympios: Some Observations on IvO No. 14, p. 112-139 ; J. Roy, The Justice of Zeus at Olympia, p. 140-149 ; F. Wojan, Charles Seltman, Le temple de Zeus et le monnayage d'argent des Éléens, p. 150-163 ; J.S. Krause, Lucian on Herodotus: A Possible Second Century AD View on the West Pediment, p. 164-185 ; A. Patay-Horváth, The East Pediment and the Temple of Zeus Reconstructed in Virtual Reality, p. 188-200; K. Sengoku-Haga, Y.Zhang, M. Lu, S. Ono, T. Oishi, T. Masuda, K. Ikeuchi, Polykleitos' Works 'From One Model': New Evidence Obtained from 3D Digital Shape Comparisons, p. 201-222; F. Gabellone, Virtual Environments and Technological Solutions for an Enriched Viewing of Historical and Archaeological Contexts, p. 223-232; Y. Okamoto, G. Kurillo, T. Oishi, K. Ikeuchi, R. Bajcsy, Cloud-Based Collaborative Framework for Remote Real-time Interaction with Large-scale 3D Data, p. 233250.

PEPE Cristina, MORETTI Gabriella (éd.), Le parole dopo la morte. Forme e funzioni della retorica funeraria nella tradizione greca e romana, Trento, Università degli Studi di Trento, 2014.

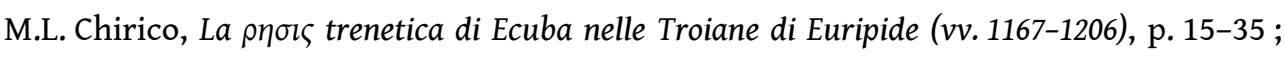

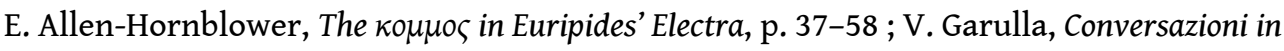
limine mortis: forme di dialogo esplicite e implicite nele iscrizioni sepolcrali greche en versi, p. 59-96 ; L. Spina, L'autoepitafio, o delle penultime volontà, p. 97-111 ; G. Moretti, Il funus, le imagines, la laudatio. Alle origini dell'impiego di visual tools a supporto dell'oratoria nella tradizione romana, p. 113-146; M. Bettini, La morte e il suo doppio. Il funerale gentilizio romano fra imagines, ridiculum e honos, p.147-178; C. Pepe, La fama dopo il silenzio: celebrazione della donna e ritratti esemplari di bonae feminae nella laudatio funebris romana, p. 179-221 ; M. Lentano, La città dei figli. Pensieri di un declamatore ai funerali di Cicerone, p. 223-244 ; S. Audano, Sopravvivere senza l'Aldilà: la consolatio laica di Tacito nell'Agricola, p. 245-288; T.S. Welch, Valerius Maximus: death as consolatio vitae, p. 289-307; A. Camerotto, Antipenthos. Antiretorica della morte nella satira di Luciano di Samosata, p. 309-330. 

Institutet i Athen, 2015 (Acta Instituti Atheniensis Regni Sueciae, 56).

T. Mühlenbruch, Power and cult in LH IIIC Tiryns, p. 131-141;O. Psychoyos, Y. Karatzikos, Mycenaean cult on Mount Arachnaion in the Argolid, p. 261-276 ;E. Konstantinidi-Syvridi, C. Paschalidis, Life and death at Mycenae at the end of the Prepalatial period. The case of the chamber tomb south of Grave Circle B. With contributions by Argyro Nafplioti and Ann Brysbaert, p. 405-431 ;M.J. Boyd, Explaining the mortuary sequence at Mycenae, p. 433-447 ; A. Philippa-Touchais, N. Papadimitriou, Deiras, Argos: The Mycenaean cemetery revisited in the light of unpublished finds from W. Vollgraff's excavations, p. 449-467;E. Pappi, V. Isaakidou, On the significance of equids in the Late Bronze Age Aegean: New and old finds from the cemetery of Dendra in context, p. 469-481; E. Konsolaki Yannopoulou, Structural analysis of the tholos tombs at Megali Magoula Galatas (Troezenia), p. 483-502 ;P. Kassimi, The Mycenaean cemeteries of north-eastern Corinthia and the early tholos tomb at Ancient Corinth, p. 503-514;C. Gillis, A colorful death. A study of the social life of colors in Late Bronze Age grave goods, p. 515-529 ;K.A. Wardle, Reshaping the past: Where was the 'Cult Centre' at Mycenae?, p. 577-596 ;V. Pliatsika, Tales of the Unexpected: Identifying cult practice in the 
House M Quarter of the Mycenae Citadel, p. 597-612;H. Whittaker, Mycenaean religion in the 21st century, p. 613-622.

51 SPORN Katja, LADSTÄTTER Sabine, KERSCHNER Michael (éd.), Natur - Kult - Raum. Akten des internationalen Kolloquiums (Paris-Lodron-Universität Salzburg, 20-22 Jänner 2012), Wien, Österreichisches Archäologisches Institut Wien, 2015.

P. Amann, Natur und Kult im vorrömischen Umbrien, p. 9-28 ; S. Berndt-Ersöz, Noise-Making Rituals in Iron Age Phrygia, p. 29-44; H. Bumke, Griechische Gärten im sakralen Kontext, p. 45-61 ; S. De Vincenzo, Etruskische Kultstätten in Berglandschaften, p. 63-79; A. Filges, Ein Felsheiligtum im Stadtgebiet von Priene. Privater Kult im öffentlichen Raum?, p. 81-109; M.-C. Forrest, S. Ortisi, Die Matronentempel in der Nordeifel. Naturheiligtümer einer autochthonen Bevölkerung?, p.111-125 ; P. Gleirscher, Vorrömerzeitliche Naturheiligtümer und die Frage ihres Fortwirkens in die Römerzeit. Fallbeispiele aus dem Ostalpenraum, p. 127151 ; A. Hefeneder, Heilige Haine der Kelten in der antiken Literatur. Kultrealität versus literarische Barbarentopik, p.153-167; M. Kerschner, Der Ursprung des Artemisions von Ephesos als Naturheiligtum. Naturmale als kultische Bezugspunkte in den großen Heiligtümern Ioniens, p. 187-243 ; S. Neumann, Inspiration aus der Tiefe - zur sakralen Bedeutung von Höhlen in griechischen Orakelheiligtümern, p. 245-266; M. Osanna, Zwischen Quellen und Gebirgsbächen: Wasser in lukanischen Heiligtümern, p. 267-280 ; F. Pirson, G. Ate, B. Engels, Die neu entdeckten Felsheiligtümer am Osthang von Pergamon - ein innerstädtisches Kultzentrum für Meter-Kybele?, p.281-301; J. Scheid, Natur und Religion. Zu einigen Missverständnissen, p. 303-312 ; H. Sedlmayer, Römische Kultplätze in Flusslandschaften die südnorischen Heiligtümer von Teurnia/St. Peter in Holz, Burgstall/St. Margarethen im Lavanttal und Podkraj bei Hrastnik, p.313-334; P.de Bernardo Stempel, Sprachwissenschaftlicher Kommentar zu den Götternamen Sabus und Adsalluta, p. 334-338; K.Sporn, Natur - Kult - Raum. Eine Einführung in Methode und Inhalt, p.339-356; L. Vandeput, Nature and Cult in Pisidia with a Focus on Pednelissos and Its Territory, p. 357378.

TIVERIOS Michalis, MISAILIDOU DESPOTIDOU Vasiliki, MANAKIDOU Eleni, ARVANITAKI Anna (éd.), Thessaloniki: Archaic Pottery of the Northern Aegean and its Periphery (700-480 BC). Proceedings of the Archaeological Meeting (Thessaloniki, 19-22 May 2011), Thessaloniki, 2012.

S.A. Fritzilas, Attic Pelike with Dionysiac Scene from Samothrace: A Work by the Theseus Painter, p. 169-178;St. Gimatzidis, Archaic Pottery in Settlements and Sanctuaries in Macedonia: Household Vessels of Mortals and Immortals at Sane in Pallene, p. 297-304; S. Moschonissioti, Archaic Pottery from the Sanctuary of Poseidon at Poseidi, Chalkidike, p. 385-398;Ch. Pardalidou, Archaic Pottery from the Sanctuary of Apollo at Ancient Zone, p. 425-435.

VILLARI Elisabetta (éd.), Il paesaggio e il sacro. L'evoluzione dello spazio di culto in Grecia: interpretazioni e rappresentazioni, Genova, De Ferrari, 2013.

Eugenia Isetti, Donatella Pian, Antonella Traverso, L'uso delle grotte come spazi cultuali in ambito mediterraneo durante la Preistoria recente, p. 17-35; Ilaria Orsi, Dal Parnaso al Golfo d'Eubea. I santuari di Delfi e Kalapodi. Elemento naturale e strategicità territoriale dalla fine del periodo miceneo all'inizio dell'epoca arcaica, p.36-48; Karl Reber, Déméter et Dionysos. Paysages sacrés sur l'île de Naxos, p. 49-58; David Bouvier, Les fontaines à tête de lion. Quand un motif sculptural invite à relire l' Iliade, p. 59-76; Chiara Tarditi, Il santuario di Atena Alea a Tegea (Grecia). Continuità di culto dall' Età Proto-Geometrica alla fine del Periodo Romano, p. 77-92 ; Anna Rita Punzo, Il mirto di Afrodite in Grecia. Attestazioni cultuali e mitologiche, p. 93-116 ; Elisabetta Villari, Dal Kepos al Témenos. Note sul paesaggio dell'Attica tra locus 
amoenus e 'giardino funerario' nell' Edipo a Colono : il bosco delle Eumenidi e l' Ur-Athen presinecistica, p.117-153 ; Leonardo Paganelli, Lo spazio scenico, teatrale, rituale, cultuale e sacrale del dramma satiresco, p. 154-176.

WALDNER Katharina, GORDON Richard, SPICKERMANN Wolfgang(éd.), Burial Rituals, Ideas of Afterlife, and the Individual in the Hellenistic World and the Roman Empire, Stuttgart, Steiner, 2016 (Potsdamer Altertumswissenschaftliche Beiträge, 57)

K. Matijeviç, The Evolution of the Afterlife in Archaic Greece, p. 15-29; J. N. Bremmer, The Construction of an Individual Eschatology: The Case of the Orphic Gold Leaves, p. 31-51 ; M. Obryk, Prote im Land der Negationen: Per negationem definiertes Nachleben in einer griechischen Grabinschrift, p. 53-66; V. Gasparini, 'I will not be thirsty. My lips will not be dry': Individual Strategies of Re-constructing the Afterlife in the Isiac Cults, p. 125-150.

WEBER Gregor (éd.), Artemidor von Daldis und die antike Traumdeutung. Texte - Kontexte Lektüren, Berlin/Boston, de Gruyter, 2015 (Colloquia Augustana, 33).

J.-J. Flinterman, Dreaming of Deities: Athena and Dionysus in the Oneirocritica, p. 161-187 ; D. Auger, La place des mythes dans l'interprétation des songes d'Artémidore, p. 189-218; G. Guidorizzi, On Dreaming of One's Mother: Oedipal Dreams between Sophocles and Artemidorus, p. 219-232;G.H. Renberg, The Role of Dream-Interpreters in Greek and Roman Religion, p. 233-262.

\section{Contributions particulières}

ARMSTRONG D., "Utility and Affection in Epicurean Friendship: Philodemus On the Gods 3, On Property Management, and Horace Sermones 2.6 ", in R.R. CASTON, R.A. KASTER (éd.), Hope, Joy, and Affection in the Classical World, Oxford, 2016 (Emotions of the Past), p. 182-208.

BIERL A., «Diachronic Shifts between the Epic Past and Future at the Phaeacians. Binding, Chorality, and Fluidity in Demodokos' Song of Ares and Aphrodite in Homer's Odyssey (8.266-366) », in J.M. GonZÁLEz(éd.),Diachrony. Diachronic Studies of Ancient Greek Literature and Culture, Berlin/Boston, 2015, p. 43-77. CAMPANelli S., «Family Cult Foundations in the Hellenistic Age: Family and Sacred Space in a Private Religious Context ", in M. HILGERT (éd.), Understanding Material Text Cultures. A Multidisciplinary View, Berlin/Boston, 2017, p. 131-202. HENRI O., "Plusieurs personnes sous un seul masque: l'interpretatio d'Artémis en Égypte", in F. COLIN, O. HUCK, S. VANSÉVEREN (éd.), Interpretatio. Traduire l'altérité culturelle dans les civilisations de l'Antiquité, Paris, 2015 (Collections de l'Université de Strasbourg. Études d'archéologie et d'histoire ancienne), p. 123-145. HERREN M.W., "Dracontius, the Pagan Gods, and Stoicism ", in S. MCGILL, J.PUCCI(éd.), Classics Renewed. Reception and Innovation in the Latin Poetry of Late Antiquity, Heidelberg, 2016, p. 297-322.

61 HIRSCH-LUIPOLD R., "The Dividing Line: Theological/Religious Arguments in Plutarch's Anti-Stoic Polemics », in J. opsomer, R. GeerT, F.B. Titchener(éd.),A Versatile Gentleman. Consistency in Plutarch's Writing. Studies offered to Luc van der Stockt on the occasion of his retirement, Leuven, 2016 (Plutarchea Hypomnemata), p. 17-36.

62 JOUANNA J., «Le Serment hippocratique : famille, religion et droit », in M.-H. MARGANNE, A. RICCIARDETTO (éd.), En marge du Serment hippocratique. Contrats et serments dans le monde 
gréco-romain. Actes de la Journée d'étude internationale (Liège, 29 octobre 2014), Liège, 2017 (Papyrologica Leodiensia, 7), p. 11-37

PAOLO BIANCHI F., « Il giudizio di bellezza delle dee nel Dionisalessandro di Cratino (POxy 663, col. I rr. 12-19) », in Matteo TAUFER(éd.),Studi sulla commedia attica, Freiburg i.Br./ Berlin/Wien, 2015 (Paradeigmata, 31), p. 231-260.

PLATT V., "Sight and the gods: on the desire to see naked nymphs », in M. SQUIRE(éd.), Sight and the Ancient Senses, London/New York, 2016 (The Senses in Antiquity), p. 161-179.

REYDAMS-SCHILS G., "'Becoming like God' in Platonism and Stoicism », in ENGBERGPEDERSEN, TROELs (éd.), From Stoicism to Platonism. The Development of Philosophy, 100 BCE 100 CE., Cambridge, 2017, p. 142-158. SCHNAPP Alain, «L'oubli et la redécouverte d'olympie des origines à l'expédition de Morée. La philosophie antique des ruines ", in A. FENET, N. LUBTCHANSK (éd.), Pour une histoire de l'archéologie XVIII siècle-1945. Hommage de ses collègues et amis à Ève GranAymerich, Bordeaux, 2015 (Scripta Receptoria, 5), p. 43-60. VAN DEN BERG B., « Eustathios on Homer's Narrative Art: the Homeric Gods and the Plot of the Iliad ", in F. PONTANI, V. KATSAROS, V. SARRIS(éd.),Reading Eustathios of Thessalonike, Berlin/Boston, 2017 (Trends in Classics, suppl. 46), p. 129-148. WESCOAT B.D., "Architectural Expectations and the Temple of Athena at Assos ", in N. ARSLAN, E.-M. MOHR, K. RHEIDT(éd.),Assos. Neue Forschungsergebnisse zur Baugeschichte und Archäologie der südlichen Troas, Bonn, 2014, p. 33-52. 